\title{
Psychoanalytic Contributions of Karl Abraham to the Freudian Legacy
}

\author{
Henrique Guilherme Scatolin \\ PUC-SP (Pontificate Catholic University of São Paulo), São Paulo, Brazil
}

\begin{abstract}
This article aims to highlight the contributions of the German psychiatrist and psychoanalyst Karl Abraham to the understanding of children pre-genital stages. From a rereading of these phases in the work of Sigmund Freud, the author highlights the Abraham contributions to it, emphasizing how Freud incorporated them throughout his work. This progress in the psychoanalytic knowledge is related to Karl Abraham observations about these pre-genital organizations, which focuses on the libido development. As a result, this article points out the oral and anal-sadistic phases subdivisions, interconnecting them with the melancholy and obsessional neurosis. It is concluded that this understanding is of utmost importance for the differential diagnosis among the narcissistic neurosis and the psychoneurosis, specifically the obsessions.
\end{abstract}

Keywords: Libido, oral stage, anal-sadistic stage, melancholy, obsessional neurosis

\section{Introduction}

This article aims to highlight the German psychoanalyst Karl Abraham contributions to Freudian psychoanalysis. To highlight these contributions, this article makes a brief bibliographical survey on Freudian work, bringing Freud's conceptions about the oral and anal-sadistic stages. Throughout this bibliographic survey, in a second moment, are highlighted the German psychoanalyst Karl Abraham contributions to that libido theory, such contributions that were incorporated into Freudian metapsychology throughout the decade of 30 .

For starting this article, we would like to emphasize that, for Freud, in the early psychic constitution, the baby is fitted with an id, and then, of a body ego (derived from the body sensations), targeting the establishment of an ideal ego narcissistically invested by the parents. On the other hand, in the libidinal development level, he claims that during the early years of a child's life there are "organizations of sexual life in the genital areas that have not yet assumed its predominant role” (Freud, 1905). These organizations are defined as pre-genital organizations (such as the oral and anal-sadistic organization) and infant genital (also known as phallic phase).

Freud initially points the anal-sadistic organization, in 1913, when publishing the article "The Disposition to Obsessional Neurosis”, and only in 1915, two years after this publication, he refers to the oral organization, when publishing the edition of the Three Assays. Thus, the notion of anal stage appears prior to the oral stage. In both organizations, the compelling is partial and their goals are the satisfaction upon appropriate stimulation of their erogenous zones.

Freud (1905) comprises erogenous zone as "a part of the skin or the mucosa where certain types of 
stimulation causes pleasurable feelings of certain quality”. These dominant erogenous zones are the mouth (in oral phase) and the anus (in anal-sadistic phase); but, in a footnote added to the Three Assays, Freud (1905) stresses that "The use of other observations led me to assign the erotogenic property to all parts of the body and all internal organs”. Freud, when deepening the discussions on the erogenous zones, understands that any point of the skin or the mucosa can take his burden as an erogenous zone. Such a claim is reiterated at the end of his work when he points out that "The most prominent parts of the body that this libido originates are known by the name of 'erogenous zones', although, in fact, the entire body is an erogenous zone of this type" (Freud, 1940).

\section{The Oral Phase}

The first pre-genital organization is the oral (or cannibalistic). For Freud (1905), in this organization, "The sexual activity has not yet separated from nutrition, nor differentiates opposing currents inside it". In this organization, there is already a division between active a passive current. Sexual pleasure is related to buccal excitement and to suction, since at the beginning of the baby's life, the psychic activity focuses on providing oral zone's needs satisfaction, such as suck milk from the mother breast and such another object to replace the mother breast, such as the baby bottle. The act of sucking on the mother breast is the main activity that provides pleasure to the baby, where his lips behave as an erogenous zone. Thus, sexuality begins to manifest itself shortly after the first satisfaction experience, during and after breastfeeding, when the baby starts sucking the mother breast and, later, a pacifier or finger, the latter being an autoerotic child sexual manifestation.

For Freud (1905), "The child act that sucks is determined by the search for a pleasure ever experienced and now remembered". The child, due to his first enjoyable experiences, strives to repeat it, since suck breast (or bottle) might provide him pleasure. In this first phase, the oral eroticism is in the foreground and the satisfaction sought through the erogenous zone of the lip when sucking her breast, thumb and pacifier aims to pursuit the previously experienced pleasure. Therefore, the erogenous oral zone persists throughout the individual life, near the erogenization of other body areas. Persisting in the erogenization, these kids, once adults, tend to be appreciative of kissing, drinking, and smoking pleasure ${ }^{1}$.

According to Freud (1921), in this organization, “The sexual target consists in the incorporation of the object, model that later will play, in the form of an identification, a psychic important role”. During the oral phase, the goal is the embodiment and the master relates that this incorporation is the prototype of the first child identifications.

On the New Conferences, when addressing the oral phase, Freud (1933) reiterates that "The erogenous zone of the mouth dominates what can be called the sexual activity from this period of life"; but shortly thereafter, declares that "This repetition (of oral phase) was necessary, so that I could use it as a starting point for an account of the progress in our knowledge”. This progress in the psychoanalytic knowledge is related to Karl Abraham thesis on pre-genital phases which focuses on the libido development.

Thus, in his contributions to Freudian metapsychology, Abraham (1921) declares:

We are obliged to admit that there is a differentiation within the oral phase of libido... In the primary level of that phase, the child's libido is linked to the sucking act. This act is the incorporation... Still there is no differentiation between the child that sucks and the breast that feeds. Furthermore, the child has no feelings of hate or love. Their mental state is

\footnotetext{
${ }^{1}$ Libido fixation points at this stage (and possible libido regressions) may develop symptoms of feeding disorders (such as anorexia and bulimia) in adulthood.
} 
therefore free, at this stage, of all ambivalence manifestations... In the biting stage of the oral phase, the individual incorporates the object in itself and, thus, destroys it... This is the state in which predominate the cannibalistic impulses. It is at this stage that the ambivalent attitude of the ego with his/her object begins to develop.

Through his clinical experience with melancholic patients, Abraham proposed to subdivide the oral procedure in two stages: the precocious oral phase (the milk suction phase) and the sadistic-oral phase (of biting). The latter corresponds to the appearance of the teeth. In this, the bite and devour activity implies an object destruction; as the first ambivalent impulses towards the embedded object begin to emerge.

Freud (1933) incorporates this subdivision in his psychosexual development theory, postulating:

We can be proud of having learned a lot of new things, especially about the first libido organizations, and we have gotten a clearer understanding of the importance of what is old; and to demonstrate this I will give you at least some examples. Abraham showed, in 1924, that one can distinguish two stages in the sadistic-anal phase... Similarly we are certain to make a similar subdivision in the first phase, the oral phase. In the first stage (the oral), what is in question is only the oral incorporation, there is absolutely no ambivalence in relation to the object-the mother breast. The second stage, characterized by the appearance of the bite activity, can be described as "oral sadistic". This shows, for the first time, the ambivalence phenomena, which becomes so clear, later, in the anal-sadistic phase.

This subdivision in Freud oral phase is maintained until the end of his work, when he says that "during this phase... sporadically already occur sadistic impulses, along with the appearance of the teeth” (Freud, 1940). The master is referring to the sadistic impulses of biting and devour the object (the mother breast) that appears at the end of the oral phase.

\section{Anal-Sadistic Phase}

The second pre-genital phase described by Freud is the anal-sadistic. In this organization, "The component instincts that dominate this pre-genital organization of sexual life are anal-erotic and the sadistic" (Freud, 1913). In this organization, the active trend (of domain) is powered by the sadism and the passive tendency by the anal eroticism.

According to Freud (1905), at this phase, "The division into opposites that pervades the sexual life is already constituted, but they still cannot be called masculine and feminine, but active and passive”. At this stage, the dominant erogenous zone is the anal. The activity is a result of the domination impulse (sadism) through the body muscles and the intestine erogenous mucosa becomes the organ of the passive sexual target (of anal eroticism). Concomitantly to the retention or expulsion of the feaces, there are partial impulses that act in an autoerotic way. So, at this stage, the opposite impulsive pairs are already developed, i.e., the ambivalence between active (sadism) and passive (masochism) is already present.

Freud (1905) emphasizes that the "intestinal catarrhs in the more early childhood leave the child 'nervous'.... In the later neurotic illness, they have a determining influence in the somatic manifestation of neurosis". The anal erogenous zone preserves, in adult life, a considerable portion of the genital excitability and, in most remote childhood, certain intestinal disorders may have provoked intense excitations. In these disorders, the boy can come to feel pleasure in erogenous stimulation while retaining the fecal mass. This retention denotes the manifestation of sadistic impulses of the child, providing him the (dis)pleasure. The constipation so frequent in childhood provides the anal zone masturbatory stimulation and may be demonstrating the child pertinacity in relation to people who take care of him. And when they grow, this game to retain faeces may be symbolically present in the special scatological rituals, in ceremonial acts and similar acts which are carefully kept confidential by the neurotic individual. Thus, these disturbances have a determining influence on neurosis 
manifestation in adulthood.

When writing Character and Anal Eroticism, Freud (1908) takes the point of view of the children who fell pleasure in feaces retention, postulating: "We deduce from such indications that these people were born with a sexual constitution in which the anal zone erogenous zone is exceptionally strong...”. In the course of psychic development, the excitements from the anal erogenous zone suffer several variations, and a large part of these excitations can be deflected of sexual purposes and directed towards other purposes, and this process is called sublimation. As a result of the anal eroticism sublimation, the triad of three characteristics is formed comprising a series of character traits: the orderly (those who fulfill their duties), parsimonious and obstinate people. Both the order, and the parsimony and obstinacy are interconnected with each other.

In addition, the master states that "The feaces are the child first gift, the first sacrifice in the name of his affection, a part of his body that is ready to share, but only with someone whom he loves" (Freud, 1918). The act of defecating offers the first opportunity for which the child must choose between a narcissistic attitude and an attitude of object love. This means that of he shares his feaces on behalf of his love or retains it with the autoerotic or aggressiveness satisfaction purpose. The child can use the feaces as an expression of defiance, symbolically denoting his hatred; or on the contrary, when ceding the feaces, he is expressing his feelings of love. Thus, the act of giving the faeces to whom this child loves is the first moment in which the boy shares a piece of his own body in order to win the favors of anybody else and this act symbolizes, primarily, the narcissistic love transition (if he retained the faeces) for the object love.

In addition to the anal eroticism fortification that can leave a great inclination to homosexuality, Freud (1933) states that the "Old interest for the feaces becomes the great value granted to gold and money...”. The interest for the money is taken from the anal-erotic sources, since the commitment on defecation disappears in later stages of adulthood, becoming the value granted to gold and money. Thus, the interest for the money enables the transfer of early impulse to this new object.

In his contributions to anal-sadistic phase, the German physician and psychoanalyst Karl Abraham (1921) says:

The psychoanalytic experience has forced us to state the existence of a pre-genital phase of libidinal development (anal phase) and we are currently taken to assume that this phase contains, in itself, two different levels. In the subsequent level, conservative trends prevail to retain and control the object, whereas in the older level, the hostile trends to the object— to destroy it and lose it—come to the foreground... This differentiation of the sadistic-anal phase in a primitive stage and another posterior appears to have a radical importance because the dividing line between these two phases provides a decisive change in the individual attitude towards the outside world.

In the New Conferences, Freud (1933) incorporates this contribution of Abraham to his theory, as he says: "We can be proud of having learned a lot of new things, especially about the first libido organizations... Abraham showed, in 1924, that one can distinguish two stages in the sadistic-anal phase”. The master is referring to the subdivision of anal-sadistic phase. The first of these stages is dominated by trends of destroying and losing, and the second stage by affectionate tends towards the objects (like the trends to maintain and possess) $)^{2}$.

According to Freud (1940), the amplitude of sadistic impulses "is much higher in the second phase (anal-sadistic) for being the so sought satisfaction in aggression and in the excretory function”. In this stage, the

\footnotetext{
${ }^{2}$ Let us remember that Abraham assigns this second tendency to obsessive neurosis and the first to melancholy.
} 
sadism comprises the impulse fusion of purely libidinal impulses (of Eros) and destructive (of Thanatos); but the master relates that "It would be a mistake to assume that these three phases (oral, anal, and phallic) succeed clearly. One may appear in addition to another; they may overlap and may be present side by side" (Freud, 1940). The predominance of one phase in relation to another does not occur so suddenly and so gradually. At the end of the oral phase, the early sadistic impulses emerge during the appearance of teeth. The baby can come to experience pleasure, in a sadistic way, when trying to suck the milk. These sadistic impulses become common in anal-sadistic phase and for being the satisfaction sought in aggression and in the excretory function. On the other hand, it is desirable to emphasize that throughout these phases (the oral and the anal-sadistic) some development inhibitions may occur leading to libido fixations. Consequently, future libido regressions during adult genital phase can cause certain psychopathologies, such as obsessional neurosis (which features a fixation on the anal-sadistic phase).

\section{Considerations}

The study of the oral and anal-sadistic phases divisions proposed by Abraham is of paramount importance for the differential diagnosis in the clinical context, as it allows a differentiation in understanding the psychic dynamics of a melancholic patient from an obsessive one.

In proposing this subdivision, this German psychoanalyst associates ambivalent impulses already present at the end of oral phase with the aggressive impulses, of attack to mother breast. In addition to these contributions to the oral phase, he also highlights the anal expulsive phase interconnecting it with melancholic destructive movements, of object annihilation. And when emphasizing the anal-retentive phase (present at the end of anal-sadistic organization), Abraham associates this with the retentive movement of object control. Therefore, the dynamics of symbolically retaining and expelling feaces can be considered a dividing line between the melancholy, in which there are movements of destruction of the identified object, and the obsessional neurosis, in which there are control movements of the beloved object.

On the other hand, these contributions from Abraham to Freudian psychoanalysis came to influence the Klenian theory of object relations, in which the British psychoanalyst has preserved this concept, using it to develop his metapsychology on the positions theory, such as his conception of envy.

\section{References}

Abraham, K. (1921/1970). Teoria Psicanalítica da Libido. Tradução de Christiano Monteiro Oiticica. 6º edição. Rio de Janeiro: Imago.

Freud, S. (1905/1996). Três Ensaios Sobre a Teoria da Sexualidade. ESB, vol. VII, Rio de Janeiro: Imago.

Freud, S. (1908/1996). Caráter e Erotismo Anal. ESB, vol. IX, Rio de Janeiro: Imago.

Freud, S. (1909/1996). Notas Sobre Um Caso de Neurose Obsessiva. ESB, vol. X, Rio de Janeiro: Imago.

Freud, S. (1913/1996). A Disposição à Neurose Obsessiva-Uma Contribuição ao Problema da Neurose. ESB, vol. XII, Rio de Janeiro: Imago.

Freud, S. (1918/1996). História de Uma Neurose Infantil. ESB, vol. XVII, Rio de Janeiro: Imago.

Freud, S. (1921/1996). Psicologia de Grupo e a Análise do Ego. ESB, vol. XVIII, Rio de Janeiro: Imago.

Freud, S. (1923/1996). O Ego e o Id. ESB, vol. XIX, Rio de Janeiro: Imago.

Freud, S. (1933/1996). Conferência XXXI-A Dissecção da Personalidade Psíquica. ESB, vol. XXII. Rio de Janeiro: Imago.

Freud, S. (1933/1996). Conferência XXXII-Ansiedade e Vida Instintual. ESB, vol. XXII, Rio de Janeiro: Imago.

Freud, S. (1933/1996). Conferência XXXI—A Dissecção da Personalidade Psíquica. ESB, vol. XXII, Rio de Janeiro: Imago.

Freud, S. (1940/1996). Esboço de Psicanálise. ESB, vol. XXIII, Rio de Janeiro: Imago.

Masson, J. M. (1986). A correspondência completa de Sigmund Freud para Wilhelm Fliess 1887-1904. Rio de Janeiro: Imago. 